TITLE:

\title{
Description of a New Brown Frog from Tsushima Island, Japan (Anura: Ranidae: Rana)
}

$\operatorname{AUTHOR}(\mathrm{S})$ :

Matsui, Masafumi

CITATION:

Matsui, Masafumi. Description of a New Brown Frog from Tsushima Island, Japan (Anura: Ranidae: Rana). Zoological Science 2014, 31(9):

613-620

ISSUE DATE:

2014-09

URL:

http://hdl.handle.net/2433/216901

RIGHT:

(C) 2014 Zoological Society of Japan 


\title{
Description of a New Brown Frog from Tsushima Island, Japan (Anura: Ranidae: Rana)
}

\author{
Masafumi Matsui* \\ Graduate School of Human and Environmental Studies, Kyoto University, \\ Sakyo, Kyoto 606-8501, Japan
}

\begin{abstract}
Because all available evidence from allozymes, mtDNA sequences, and artificial hybridization suggests presence of high genetic differentiation between populations of East Asian brown frogs currently assigned to Rana dybowskii Günther, 1876, I compared morphological characters between specimens from Tsushima Island of Japan and Maritime territory of Russia. The population from Tsushima is slightly, but significantly different from $R$. dybowskii from Russia, including the holotype. I therefore consider the Tsushima population to be specifically distinct, and describe it as a new species $R$. uenoi. The new species also occurs in the Korean Peninsula and adjacent islands, but the distributional relationships with $R$. dybowskii are unclear, as detailed distribution in northern Korea is lacking.
\end{abstract}

Key words: East Asia, Korea, new species, Rana dybowskii, Rana uenoi, Tsushima Island

\section{INTRODUCTION}

Brown frogs of the true frog genus Rana from East Asia are separated by the number of diploid chromosomes, one with $2 n=24$ and another with $2 n=26$ (e.g., Seto, 1965; Green, 1983). Members of the former group are very similar morphologically and have a complex taxonomic history (e.g., Matsui et al., 1993; Tanaka-Ueno et al., 1998). Rana dybowskii is an example of such cases. The species was originally described from Abrek Bay, near Vladivostok, Maritime Territory of Russia by Günther (1876), and has some synonymies, such as $R$. semiplicata Nikolskii, 1918 and $R$. zografi Terentjev, 1922. Later, the species was thought to occur in the Korean Peninsula and Tsushima Island of Japan, and was treated as a subspecies of European R. temporaria Linnaeus, 1758 (Shannon, 1956) or Chinese R. chensinensis (Uéno and Shibata, 1970), but karyological evidence revealed the absence of $R$. temporaria in East Asia. Moreover, morphological (Matsui et al., 1993) and molecular (Tanaka-Ueno et al., 1999) evidence also rejected the conspecificity of the brown frogs around the Japan Sea coasts, including the Maritime Territory, with topotypic $R$. chensinensis, and confirmed the specific validity of $R$. dybowskii.

However, presence of intraspecific variation had been suggested in R. dybowskii prior to the establishment of its distinct species status. Matsui (1991), Nishioka et al. (1992), and Green and Borkin (1993 as R. chensinensis semiplicata) independently analyzed isozymes and equivocally found great genetic divergence between $R$. dybowskii from the Maritime Territory and the brown frog from Tsushima or

\footnotetext{
* Corresponding author. Tel. : : +81-75-753-6846; Fax : +81-75-753-6846; E-mail: fumi@zoo.zool.kyoto-u.ac.jp
}

Korea. Analyses of the sequence of mitochondrial cytochrome b gene in $R$. dybowskii revealed that differentiation is minimal between the Tsushima and Korea but marked between them and the Russian population (Tanaka-Ueno et al., 1998; Matsui et al., 1998). Matsui et al. (1998), thus, suggested the separation of Tsushima and Korean populations from Russian population at the specific level. However, to date the morphological comparisons of these populations necessary for taxonomic decision have not been made. In this paper, by analyzing morphological variations among populations from Tsushima and Russia, including the holotype of $R$. dybowskii Günther, 1876 housed in Natural History Museum, London (BMNH 1947.2.1.79), and compiling all available information, I describe the Tsushima population as a new species.

\section{MATERIALS AND METHODS}

I examined specimens of $R$. dybowskii from Tsushima and Russia preserved in $70 \%$ ethanol and stored at the Graduate School of Human and Environmental Studies, Kyoto University (KUHE), the Graduate School of Science, Kyoto University (KUZ), the Osaka Museum of Natural History $(\mathrm{OMNH})$, and the National Museum of Nature and Science, Tokyo (NSMT).

For all adult specimens, I took the following 16 body measurements to the nearest $0.1 \mathrm{~mm}$ with dial calipers, basically following Matsui (1984) and Matsui et al. (2013): (1) snout-vent length (SVL); (2) head length (HL), (3) snout length (SL); (4) eye length (EL); (5) eye diameter (ED); (6) tympanum diameter (TD); (7) head width (HW); (8) internarial distance (IND); (9) interorbital distance (IOD); (10) upper eyelid width (UEW); (11) lower arm and hand length (LAL); (12) hindlimb length (HLL); (13) thigh length (THIGH); (14) tibia length (TL); (15) foot length (FL); and (16) inner metatarsal tubercle length (IMTL). The system of description of toe-webbing states followed that used by Savage (1975). In the univariate comparisons, SVL was compared by Tukey-Kramer test, while the ratios (R) of the remaining characters to SVL were compared by Dunn's multiple comparisons test. The significance level was set at 0.95 .

For preserved larvae, the following 13 measurements were 
taken to the nearest $0.01 \mathrm{~mm}$ using a binocular dissecting microscope equipped with a micrometer: (1) total length (TOTL); (2) head-body length (HBL); (3) maximum head-body width (HBW); (4) maximum head-body depth (HBD); (5) eyeball diameter; (6) internarial distance; (7) interorbital distance; (8) snout-spiracle opening distance; (9) oral disk width; (10) tail length; (11) maximum tail depth; (12) maximum tail width, and (13) muscle depth at middle of tail. For staging, Gosner's (1960) table was followed.

Recording of frog calls was made in the field using a digital recorder (Olympus LS-11) at $44.1 \mathrm{kHz} / 16$ bit as uncompressed wave files and analyzed with Raven Lite 1.0 for Mac OS X (http:// www.birds.cornell.edu/raven) on a Macintosh computer. I obtained temporal data from the oscillograms and frequency information from the audiospectrograms using Fast Fourier Transformation (1024 point Hanning window).

\section{SYSTEMATICS}

Rana uenoi sp. nov.

(Japanese name: Chosen-Yama-Aka-gaeru)

(Figs. 1-3)

Rana (Rana) temporaria subsp.: Nakamura and Uéno, 1963, p. 42.

Rana (Rana) ornativentris subsp.: Nakamura and Uéno, 1965, p. 42.

Rana chensinensis dybowskii: Uéno and Shibata, 1970, p. 194.

Rana dybowskii: Sengoku, 1979, p. 144.

\section{Diagnosis}

A moderate-sized Rana (SVL to about $76 \mathrm{~mm}$ in females and $62 \mathrm{~mm}$ in males) of the Rana temporaria group; a dark mask covering tympanum; males with internal vocal sacs; diploid chromosome, $2 n=24$; very similar in appearance to $R$. dybowskii, but has significantly longer head, tibia, thigh, and hindlimb, wider internarial distance, and larger eye in males, and longer hindlimb in females, all in relative size to SVL, than $R$. dybowskii; tibiotarsal articulation of adpressed limb reaching mostly the point between anterior corner of eye and nostril in females, and between nostril and tip of snout in males, unlike $R$. dybowskii (to anterior corner of eye in females, and between anterior corner of eye and nostril in males).

\section{Etymology}

The specific epithet is dedicated to Dr. Shun-ichi Uéno, Emeritus Curator of NSMT, who is an eminent entomologist and also contributed greatly to the elucidation of Japanese amphibian fauna.

\section{Holotype}

KUHE 43484, an adult male from Mitake, Kamiagatamachi, Tsushima-shi, Nagasaki Prefecture, Japan (36 $34^{\prime} 36^{\prime \prime} \mathrm{N}, 129^{\circ} 22^{\prime} 25^{\prime \prime} \mathrm{E}, 160 \mathrm{~m}$ a.s.l.), collected on 19 September 2009 by Takafumi Nakano.

\section{Paratypes}

All from Tsushima Island, Tsushima-shi, Nagasaki Prefecture, Japan. Izuhara-machi: OMNH Am 5486 from Kamizaka, Kitazato on 17 September 1977 by O. Tominaga. Kamiagata-machi: OMNH Am 2570 from Usseki, Sago on 24 May 1965 by Y. Shibata; OMNH Am 2801, 2802 from Mitake (ca. $400 \mathrm{~m}$ a.s.I.) on 27 July 1970 by Y. Nishikawa;
OMNH Am 2927, 2928 from Sago on 22 August 1962 by Y. Tomoda; NSMT 00034 from Mt. Tatera-yama on 20 October 1969 by S.-I. Uéno; NSMT 01956 from Sago in February 1961 by $Y$. Imaizumi; KUHE 43474 from Mitake on 19 September 2009 by T. Nakano; KUHE 48370, 48371 from Nakayama on 13 February 2014 by K. Eto; KUHE 48372 , 48373 from Nishisato on 13 February 2014 by K. Eto; KUHE 48374, 48375 from Nakayama on 12 July 2013 by K. Matsuo. Mine-machi: KUHE 48232 from Minegawa (34 $\left.28^{\prime} 44^{\prime \prime} \mathrm{N}, 129^{\circ} 19^{\prime} 42^{\prime \prime} \mathrm{E}\right)$ on 15 October 1983 by S. Takenaka and S. Sengoku. Mitsushima-machi: KUHE 1127411278, 11300, 11595-11598 from Kechi on 21 September 1990 by M. Matsui and J. Wilkinson; KUHE 16784-16790 from Kechi on 26 February 1994 by Y. Misawa and K. Kasugai. Toyotama-machi: NSMT 00037 from Nii on 8 July 1969 by I. Obara.

\section{Referred specimens}

Tsushima-shi, Japan. KUHE unnumbered five tadpoles from reared eggs from Nakayama, Kamitsushima-machi collected on 13 February 2014 by K. Eto.

Korea. Gangwon-do: KUHE 14016-14031 on October 1992 by N.-K. Paik. Gyeonggi-do: KUHE 47255-47257 (former KUZ 46677-46679), KUHE 48268 (former KUZ 46680) from Kwangnung, on 18 October 1998 by S.-L. Chen. Cheju Island: KUHE 47254 (former KUZ 46594) from Kyorae-ri, $650 \mathrm{~m}$ a.s.I., on 15 October 1998 by S.-L. Chen and H.-S.

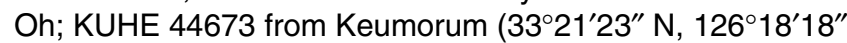
E, $369 \mathrm{~m}$ a.s.I.) on 27 April 2011 by M. Matsui, T. Hikida, and H.-S. Oh; KUHE 44680 from Cheonwansa (33 $25^{\prime} 20^{\prime \prime}$ $\mathrm{N}, 126^{\circ} 29^{\prime} 14^{\prime \prime} \mathrm{E}, 542 \mathrm{~m}$ a.s.I.) on 2 May 2011.5 .2 by $\mathrm{M}$. Matsui, T. Hikida, and H.-S. Oh.

\section{Description of holotype (in millimeters)}

SVL 57.8; body robust; head nearly as wide (HW 20.2, $34.9 \%$ SVL) as long (HL 20.4, 35.3\% SVL); snout triangular, but tip rounded in dorsal outline; projecting beyond lower jaw, slightly rounded in lateral profile; canthus rostralis fairly distinct; lore oblique, slightly concave; nostril below canthus, midway between tip of snout (S-NL 3.8, 6.6\% SVL) and anterior margin of upper eyelid; internarial distance (IND 3.9, $6.8 \% \mathrm{SVL}$ ) subequal to distance from nostril to eye (N-EL 3.8, 6.6\% SVL); eye moderate, length (EL 7.1, 12.3\% SVL) twice eye-nostril distance and smaller than snout length (SL 8.3, 14.4\% SVL); interorbital (IOD 3.4, 5.9\% SVL) narrower than width of upper eyelid (UEW 5.3, 9.2\% SVL) and internarial distance; tympanum distinct, nearly circular (TD 4.3, $7.4 \%$ SVL), about four-sevenths eye diameter; vomerine teeth in oval, small, and slightly oblique raised series (each of 5 teeth), the center posterior to line connecting posterior margins of choanae, narrowly separated from each other, but widely separated from choanae; tongue narrow anteriorly, moderately notched, without papilla; a pair of internal vocal sacs and vocal openings on corners of mouth.

Forelimb stout (FLL 38.3, 66.3\% SVL; LAL 28.3, 49.0\% SVL); fingers not slender, unwebbed; finger length formula: II $<$ I $<$ IV < III (Fig. 3A), first finger only slightly longer than second; finger tips blunt, without disk; no fringes of skin along fingers; three large palmar tubercles, and an indistinct supernumerary tubercle; subarticular tubercles prominent, circular; distinct gray nuptial pads on dorsal, medial, and 


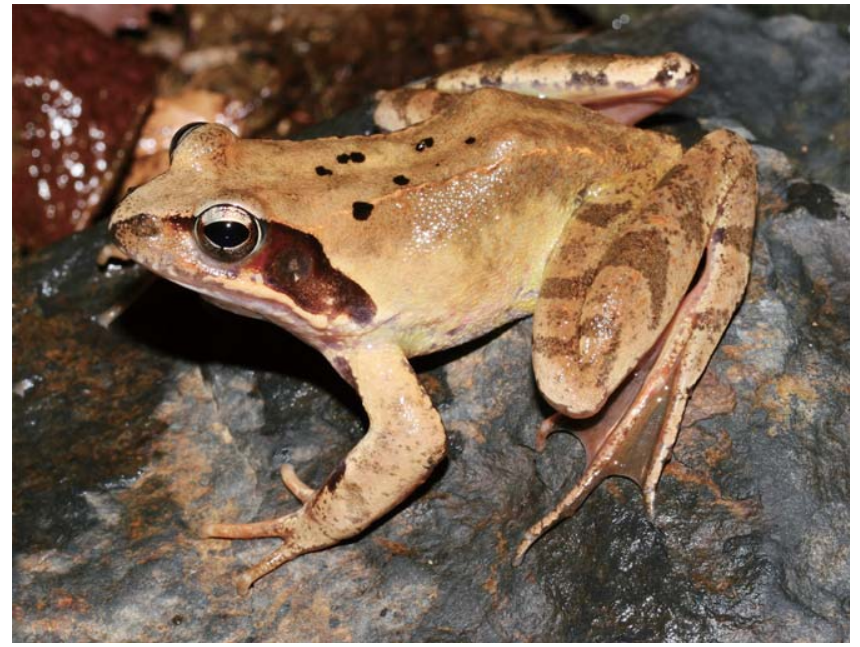

Fig. 1. Dorsolateral view of a male holotype of Rana uenoi sp. nov. (KUHE 43484) in life.

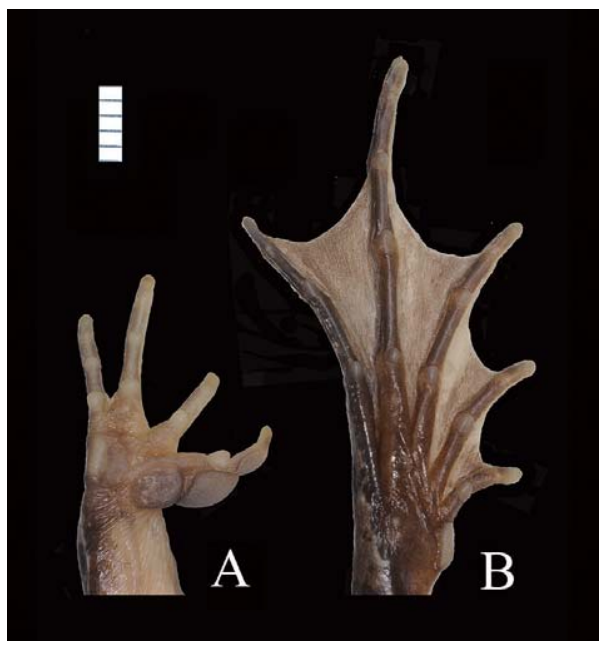

Fig. 3. Ventral views of right hand (A) and foot (B) of male holotype of Rana uenoi sp. nov. (KUHE 43484). Scale bar $=5 \mathrm{~mm}$.

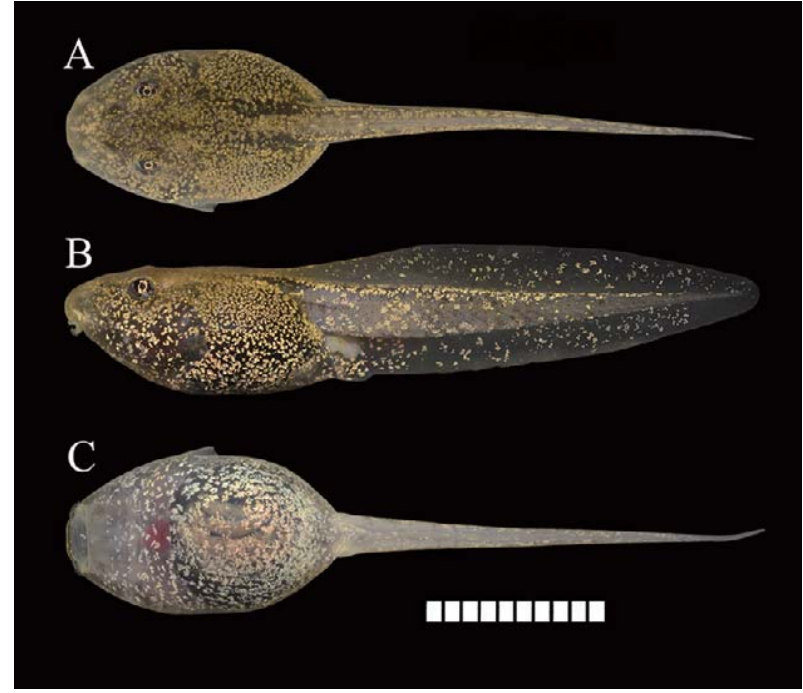

Fig. 4. Dorsal (A), lateral (B), and ventral (C) views of larval Rana uenoi sp. nov. from Nakayama, Kamitsushima-machi, Tsushima Is. (Stage 33, total length $=37 \mathrm{~mm}$ ). Scale bar $=10 \mathrm{~mm}$.

ventral surfaces of first finger extending from its base to distal phalanx, covered with minute asperities medially.

Hindlimb long (HLL104.0, 179.9\%SVL), about 2.7 times the length of forelimb; tibia (TL 32.8, 56.4\%SVL) shorter than foot (FL 35.8, 61.9\%SVL); heels well overlapping when limbs are held at right angles to body; tibiotarsal articulation of adpressed limb reaching nostril; toe tips blunt, without disk; toe length formula I $<$ II $<$ III $<$ V $<$ IV; third toe slightly shorter than fifth; toes moderately webbed, formula | 1-2 II 1-2 III 1-3 IV $2 \frac{1}{2}-1 \mathrm{~V}$ (Fig. 3B); excision of membrane between two outer toes reaching middle subarticular tubercle of fourth when toes in contact; webs thick, not crenulate; subarticular tubercles prominent, oval; inner metatarsal tubercle distinct, oblong (IMTL 3.5, 6.1\%SVL), half length of first toe $(7.3,12.6 \% \mathrm{SVL})$; outer metatarsal tubercle small and indistinct; sides of tarsus not forming tarsal fold.

Dorsal skin smooth with few weak tubercles; chevron marking in scapular region hardly recognizable; supratympanic fold from posterior margin of eye above and behind tympanum to above arm insertion; dorsolateral fold from supratympanic fold to groin; sides scattered with small tubercles; ventral skin smooth.

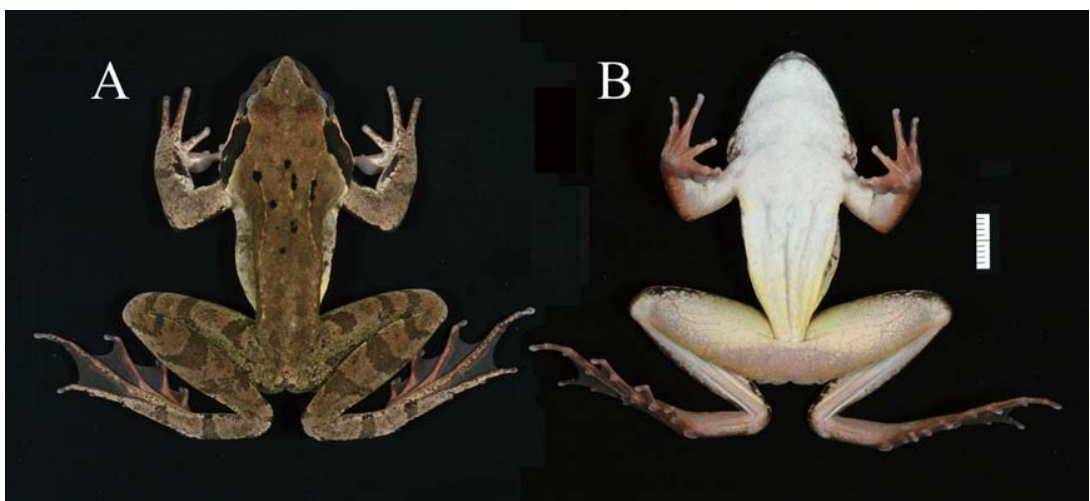

Fig. 2. Dorsal (A) and ventral view (B) of male holotype of Rana uenoi sp. nov. (KUHE 43484). Scale bar $=10 \mathrm{~mm}$.

\section{Color}

In life, reddish brown dorsally on head and body with several black spots between scapular and sacral region (Figs. 1, 2A); trace of dark brown interorbital bar; no vertebral line; dorsolateral fold lighter than ground dorsal color; lore with narrow dark brown marking below canthus; light gray marking on labial; a distinct black marking from behind eye, covering tympanum and reaching above arm insertion; dorsal surfaces of limbs marked with alternating, dark brown crossbars, one on forearm, three on thigh and tibia, and two on tarsus; throat, chest, and abdomens creamy white, with 
trace of yellow posteriorly (Fig. 2B); ventral surface of legs white tinged with light yellowish orange; hand and foot ventrally light grayish tinged with red; iris gold with small reddish portions anteriorly and posteriorly. In preservative, the dorsal ground coloration has become darkened, but otherwise no obvious change in color or pattern has occurred, except for appearance of several faint brown spots on abdomen.

\section{Variation}

A summary of morphometric data is shown in Table 1 together with those on the allied species, $R$. dybowskii. Females are significantly larger in SVL (mean \pm SD $=69.4 \pm$ $5.4 \mathrm{~mm}, n=12)$ than males $(57.5 \pm 3.2 \mathrm{~mm}, n=16$; TukeyKramer test, $P<0.01$ ). Relative lengths of internarial distance, lower arm, and head width are significantly greater in males than females (Mann-Whitney U-test, two-tailed, $P<$ 0.05). When the hindlimb is bent forward along the body, tibiotarsal joint usually reaches between snout and nostril in males, but in females, the joint reaches between nostril and anterior corner of eye. Degree of development of the outer metatarsal tubercle varies and most specimens possess a

Table 1. Measurements in adults of Rana uenoi sp. nov. and $R$. dybowskii. $S V L$ (mean $\pm 1 S D$, in $\mathrm{mm}$ ) and medians of ratios $(R)$ of other characters to SVL, followed by ranges in parenthesis. See text for character abbreviations.

\begin{tabular}{|c|c|c|c|c|c|}
\hline & \multicolumn{2}{|c|}{ R. uenoi } & \multicolumn{3}{|c|}{ R. dybowskii } \\
\hline & 16 males & $12 \mathrm{fem}$ & $\begin{array}{c}\text { male } \\
\text { holotype }\end{array}$ & 18 males & 8 females \\
\hline $\mathrm{VL}$ & $\begin{array}{c}57.5 \pm 3.2 \\
(51.3-62.3)\end{array}$ & $\begin{array}{c}69.4 \pm 5.4 \\
(58.7-75.6)\end{array}$ & 62.3 & $\begin{array}{c}56.2 \pm 4.8 \\
(50.9-67.4)\end{array}$ & $\begin{array}{l}5.3 \\
74.2)\end{array}$ \\
\hline $\mathrm{RHL}$ & $\begin{array}{c}35.8 \\
(33.2-37.0)\end{array}$ & $\begin{array}{c}34.8 \\
(33.1-37.4)\end{array}$ & 36.9 & $\begin{array}{c}33.5 \\
(31.5-35.7)\end{array}$ & $\begin{array}{c}32.5 \\
(30.0-34.5)\end{array}$ \\
\hline RSL & $\begin{array}{c}14.7 \\
(13.0-16.2)\end{array}$ & $\begin{array}{c}14.6 \\
(13.2-15.8)\end{array}$ & 14.8 & $\begin{array}{c}13.7 \\
(12.9-15.3)\end{array}$ & $\begin{array}{c}13.6 \\
(12.6-15.4)\end{array}$ \\
\hline RIND & $\begin{array}{c}7.9 \\
(6.7-10.3)\end{array}$ & $\begin{array}{c}7.2 \\
(6.6-8.9)\end{array}$ & 7.1 & $\begin{array}{c}7.1 \\
(6.4-8.8)\end{array}$ & $\begin{array}{c}6.7 \\
(6.3-7.8)\end{array}$ \\
\hline RIOD & $\begin{array}{c}6.0 \\
(5.3-7.0)\end{array}$ & $\begin{array}{c}5.9 \\
(5.1-7.2)\end{array}$ & 6.3 & $\begin{array}{c}6.6 \\
(4.4-7.5)\end{array}$ & $\begin{array}{c}6.5 \\
(5.2-7.4)\end{array}$ \\
\hline RUEW & $\begin{array}{c}8.3 \\
(7.0-9.2)\end{array}$ & $\begin{array}{c}8.2 \\
(7.4-9.4)\end{array}$ & 8.2 & $\begin{array}{c}7.6 \\
(6.7-9.0)\end{array}$ & $\begin{array}{c}7.5 \\
(7.0-8.5)\end{array}$ \\
\hline REL & $\begin{array}{c}13.5 \\
(12.0-14.9)\end{array}$ & $\begin{array}{c}12.4 \\
(10.8-14.3)\end{array}$ & 12.0 & $\begin{array}{c}12.6 \\
(11.0-14.1)\end{array}$ & $\begin{array}{c}11.1 \\
(10.7-12.8)\end{array}$ \\
\hline RED & $\begin{array}{c}11.3 \\
(10.5-12.6)\end{array}$ & $\begin{array}{c}10.9 \\
(9.8-11.6)\end{array}$ & 10.9 & $\begin{array}{c}10.0 \\
(9.5-11.7)\end{array}$ & $\begin{array}{c}9.3 \\
(8.7-10.6)\end{array}$ \\
\hline RTD & $\begin{array}{c}7.2 \\
(5.9-8.4)\end{array}$ & $\begin{array}{c}6.6 \\
(5.5-7.9)\end{array}$ & 6.1 & $\begin{array}{c}7.0 \\
(6.4-8.3)\end{array}$ & $\begin{array}{c}7.1 \\
(6.0-7.6)\end{array}$ \\
\hline RHW & $\begin{array}{c}34.9 \\
(32.8-36.7)\end{array}$ & $\begin{array}{c}34.1 \\
(32.1-37.0)\end{array}$ & 34.0 & $\begin{array}{c}34.2 \\
(29.8-36.8)\end{array}$ & $\begin{array}{c}32.7 \\
(30.6-34.8)\end{array}$ \\
\hline RLAL & $\begin{array}{c}47.7 \\
(43.6-52.3)\end{array}$ & $\begin{array}{c}44 \\
(42.1-47.4)\end{array}$ & 46.9 & $\begin{array}{c}46.7 \\
(44.0-50.8)\end{array}$ & $\begin{array}{c}42.7 \\
(40.6-44.7)\end{array}$ \\
\hline RFL & $\begin{array}{c}60.4 \\
(55.4-65.9)\end{array}$ & $\begin{array}{c}58.4 \\
(53.2-62.2)\end{array}$ & 61.8 & $\begin{array}{c}60.2 \\
(56.3-67.0)\end{array}$ & $\begin{array}{c}54.5 \\
(52.6-57.0)\end{array}$ \\
\hline RTL & $\begin{array}{c}57.0 \\
(54.0-62.5)\end{array}$ & $\begin{array}{c}55.8 \\
(53.0-58.6)\end{array}$ & 53.3 & $\begin{array}{c}53.8 \\
(49.8-58.4)\end{array}$ & $\begin{array}{c}52.4 \\
(48.3-54.3)\end{array}$ \\
\hline RTHIGH & $\begin{array}{c}53.4 \\
(51.0-56.4)\end{array}$ & $\begin{array}{c}52.3 \\
(50.1-53.8)\end{array}$ & 50.4 & $\begin{array}{c}50.1 \\
(45.3-54.9)\end{array}$ & $\begin{array}{c}49.5 \\
(45.7-54.6)\end{array}$ \\
\hline RHLL & $\begin{array}{c}184.4 \\
(154.5-202.5)\end{array}$ & $\begin{array}{c}177.1 \\
(169.1-185.4)\end{array}$ & 175.9 & $\begin{array}{c}178.6 \\
(165.2-191.4)\end{array}$ & $\begin{array}{c}169.5 \\
(148.1-172 .\end{array}$ \\
\hline RIMTL & $\begin{array}{c}5.8 \\
(5.2-6.5)\end{array}$ & $\begin{array}{c}5.6 \\
(5.1-6.5)\end{array}$ & 5.6 & $\begin{array}{c}5.8 \\
(4.3-6.7)\end{array}$ & $\begin{array}{c}5.9 \\
(4.8-6.6)\end{array}$ \\
\hline
\end{tabular}

rudimentary tubercle or lack it. Males tend to have more developed toe webbing than females, and the modes of phalanges free of web in females and males are 1 and $1 / 2$ on outer side of second, $2 \frac{1}{2}$ and 2 on outer side of fourth, and 1 and $1 / 2$ on inner side of fifth toe, respectively. Some have dorsum scattered with small tubercles, and trace of a chevron marking in scapular region. Individuals change their dorsal ground color from pinkish orange to dark brown. In addition to ground body color metachrosis, individuals are variable in coloration. A few individuals have black spots between scapula and sacrum, and some have a barred lower lip. Totally milky white ventrum as in the holotype is rare, and most of the paratypes are more or less marked with brown ventrally. Some have markings only on throat and anterior abdomen, and the other, especially females, are heavily marked on throat and whole abdomen. These markings are reddish in life, but change to light to dark brown in preserved specimens. Ventral side of limbs is often tinged with pink even after preservation.

\section{Eggs and larvae}

Eggs are laid in a rather small globular mass, and the swollen jelly layer is tough. The clutch size is about 1700 . The diameter of ovarian eggs from a female varies from 1.5-1.8 (mean $\pm \mathrm{SD}=1.61 \pm 0.10$, $n=10) \mathrm{mm}$. The animal hemisphere of egg is dark brown in color.

A total of six tadpoles in stages 35-36 (TOTL = 38.5-43.2 [mean $\pm \mathrm{SD}=41.3 \pm 1.8] \mathrm{mm}, \mathrm{HBL}=$ 14.4-17.6 [mean $\pm S D=15.4 \pm 1.3$ ] $\mathrm{mm}$ ), from reared eggs from Nakayama, Kamitsushima-machi, were closely examined. Head and body slightly flattened above, spheroidal below; HBW maximum at level of spiracle $56-72 \%$ (median $=66 \%$ ) of $\mathrm{HBL}$; HBD $82-85 \%$ (median $=84 \%$ ) of HBW; snout rounded; eyes dorsolateral, not visible from below, eyeball $9-11 \%$ (median $=11 \%$ ) of $\mathrm{HBL}$; interorbital moderate, $126-161 \%$ (median $=132 \%$ ) of eyeball diameter; nostril open, dorsolateral, rim raised, midway between tip of snout and eye; internarial $71-84 \%$ (median $=76 \%$ ) of interorbital. Oral disk anteroventral, emarginate, width $23-29 \%$ (median $=27 \%$ ) of HBW; marginal papillae on upper labium with wide gap, short papillae in one row at corners, submarginal papillae present; lower labium with a continuous row of papillae, submarginal papillae present near corners; denticles 4(2-4)/4(1-2); beaks with black outer margins; outer surface smooth; margin finely serrate; upper beak weekly convex medially; neither beak divided. Spiracle sinistral, opening 51$67 \%$ (median $=63 \%$ ) of HBL; tube pointing upward and backward, free of body wall slightly. Anal tube dextral, attached to ventral fin; thick loops of gut visible ventrally. Tail moderately long and lanceolate, both margins weakly convex, tapering gradually to slightly rounded tip; tail length 145-194\% (median = $166 \%$ ) of $\mathrm{HBL}$, maximum depth $30-35 \%$ (median = $33 \%$ ) of length; dorsal fin origin at posterior end of body, deeper than ventral fin except near tail tip; ventral fin origin continuous to vent; caudal muscle moderately strong, maximum tail width 28-35\% 
(median $=31 \%$ ) of HBW; muscle depth at middle of tail 31$35 \%$ (median $=31 \%$ ) of tail depth, steadily narrowed posteriorly, shallower than either fin in distal half of tail. Indistinct supranaso-orbital, infranaso-orbital, mental, and pregular lateral line pores discernible. In life dorsal and lateral body brown densely covered with golden except for temporal region between eye and anterior abdomen, and paravertebral region on posterior dorsum to base of upper tail muscle, that are dark brown sparsely scattered with golden; venter grey scattered with silver; tail scattered with black and golden or silver spots (Fig. 4). In formalin head-body dark gray brown dorsally and laterally, scattered with small silver spots anterodorsally; caudal muscle light gray with dark brown mottling; fins scattered with small dark spots.

\section{Karyotype}

$2 n=24$, with five large and seven small pairs. Chromosome Nos. 1, 2, 3, and 5 in the larger group and Nos. 7 and 8 in the smaller group are metacentric, while No. 4 in the larger group and Nos. 10 and 12 in the smaller group are submetacentric. Small chromosomes Nos. 6, 9, and 11 are subtelocentric. The small chromosome No. 10 has a distinct secondary constriction in the longer arm (Nishioka et al., 1987).

\section{Call}

Mating calls of a single male, recorded at Nakayama, Kamitsushima-machi on 13 February 2014 by Koshiro Eto at the air temperature of $4.7^{\circ} \mathrm{C}$ were analyzed. Each call is emitted with the interval of 5.1-151.5 (mean \pm SD $=28.8 \pm$ $41.7, n=11) \mathrm{s}$, and consists of $4-8(6.6 \pm 1.00, n=12)$ notes, with a note repetition rate of 7.3-8.3 (7.69 $\pm 0.31, n=$ 12). The call duration varies from $480 \mathrm{~ms}$ with four notes to 1042 ms with 8 notes $(814.7 \pm 141.7, \mathrm{n}=12)$, and the note duration is $37-129(75.1 \pm 17.7, \mathrm{n}=80) \mathrm{ms}$. Each note is emitted at an interval of 32-87 $(57.3 \pm 11.5, n=68) \mathrm{ms}$, and a gap of $76-154(129.4 \pm 13.1, n=68) \mathrm{ms}$. Each note is composed of many fine pulses, and shows clear harmonics, each with conspicuous frequency modulation. The fundamental frequency measured at the mid point varies from $0.5-0.8(0.61 \pm 0.05, n=80) \mathrm{kHz}$, and the maximum frequency of $3.1-3.5(3.31 \pm 0.14, n=12) \mathrm{kHz}$ is observed at the third to seventh (mean $\pm S D=5.3 \pm 1.1, n=12$ ) note. The dominant frequency corresponds to the second harmonic, and varies from 1.1-1.4 (1.22 $\pm 0.09, n=80) \mathrm{kHz}$ (Fig. 5).

\section{Comparisons}

Among Asian members of brown frogs, R. uenoi most resembles $R$. dybowskii with which it was long synonymized. In males, $R$. uenoi has significantly longer head, tibia, thigh, and hindlimb, wider internarial distance, and larger eye in males, and longer hindlimb in females, all in relative size to SVL, than $R$. dybowskii (Mann-Whitney Utest, two-tailed, $P<0.05)$. Also ratios of interorbital distance to internarial distance (IOD/IND) and upper eyelid width (IOD/UEW) are larger in $R$. uenoi than in $R$. dybowskii in both sexes. Rana uenoi, with tibiotarsal articulation of adpressed limb reaching mostly the point between anterior corner of eye and nostril in females, and between nostril and tip of snout in males, differs from $R$. dybowskii, in which the

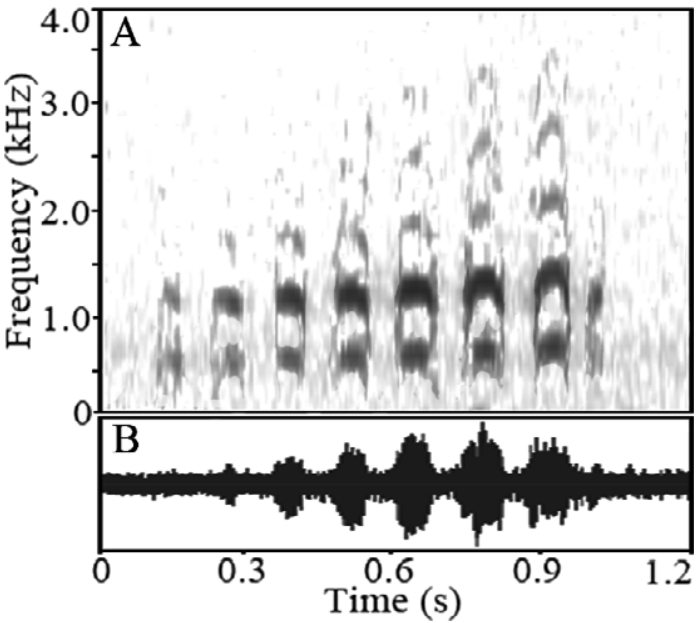

Fig. 5. Sonogram (A) and waveform (B) showing an advertisement call of a paratype of Rana uenoi sp. nov. (KUHE 48370) from Tsushima Is., recorded at an air temperature of $4.7^{\circ} \mathrm{C}$.

articulation reaching to anterior corner of eye in females, and between anterior corner of eye and nostril in males.

From the remaining East Asian brown frog species with $2 n=24$ chromosomes, $R$. uenoi differs in the following way: Rana uenoi differs from $R$. ornativentris Werner, 1903 in the usual absence of light stripe on middorsal line and outer metatarsal tubercle (vs. usually with a stripe and a distinct tubercle in $R$. ornativentris). Also, in $R$. uenoi, dark bars on tibia are less numerous $(0-4$ [median $=3$ ] vs. $3-6$ [median $=$ 4.5 ] in $R$. ornativentris). From $R$. pirica Matsui, 1991, $R$. uenoi differs by the tibiotarsal joint reaching mostly at least the point beyond the anterior corner of eye even in females (vs. the joint reaching at most to the anterior corner of the eye even in males that have longer limbs than in females in $R$. pirica). Rana uenoi also differs from $R$. pirica in nearly smooth dorsal skin (vs. with a few tubercles in $R$. pirica), usually thin dorsolateral fold (vs. fold thick in $R$. pirica), frequent absence of dark spots on flanks (vs. usually with a few dark spots in $R$. pirica), limited development of dark markings on the abdomen (vs. markings usually covering the abdomen in $R$. pirica), and usual absence of outer metatarsal tubercle (vs. tubercle variously developed, but usually indistinct in R. pirica: Matsui, 1991).

Rana uenoi has relatively narrow internarial (IND) in both sexes, and is smaller in relative interorbital space (IOD) and relative size of head $(\mathrm{HL}$ and $\mathrm{HW})$ in males than $R$. chensinensis David, 1875 (Matsui et al., 1993: R. uenoi treated as $R$. dybowskii from Tsushima). Additionally, $R$. uenoi, with reddish brown ventrum in life differs from $R$. chensinensis (vs. ventrum yellowish white or yellowish green in $R$. chensinensis: Fei et al., 2005). Female $R$. uenoi (as R. temporaria dybowskii) is reported to possess oviducts that absorb water in preservative, which oviducal property is lacking in Chinese $R$. chensinensis (as $R$. $t$. chensinensis: Shannon, 1956).

From $R$. asiatica Bedriaga, 1898, R. uenoi differs by distinctly divided male nuptial pad, and lack of markedly sloping lore and dark stripes on dorsum (vs. lore markedly sloping laterally, dorsum with fairly wide, interrupted dark stripes 
running parallel, and nuptial pad not clearly divided in $R$. asiatica: Fei et al., 2005). Rana uenoi, with relatively smooth dorsal skin, with few, small tubercles, and the tibio-tarsal articulation reaching mostly to the point between anterior corner of eye and nostril in females, and between nostril and tip of snout in males, differs from R. kukunoris Nikolskii, 1918 (vs. dorsal skin rough, tubercles large and numerous, and tibiotarsal articulation reaching to tympanum in $R$. kukunoris: Fei et al., 2005). Rana uenoi, with paired internal vocal sacs, differs from $R$. huanrensis Fei, Ye, and Huang, 1990, which lacks vocal sacs. Additionally, by a milky white ground color of male ventrum, and the red color patched over the throat and chest in breeding females, $R$. uenoi can be differentiated from $R$. huanrensis (vs. ventrum yellowish gray with minute black dots densely distributed over the throat and chest, and breeding females with throat and chest covered with yellowish green in $R$. huanrensis: Kim et al., 2002).

Uncorrected sequence divergences of $R$. uenoi $16 \mathrm{~S}$ rRNA sequences (455 bp) and all homologous sequences of its relatives are: $4.6-5.5 \%$ between $R$. dybowskii, $4.4-4.9 \%$ between $R$. ornativentris, 3.5-4.4\% between $R$. pirica, 3.5$4.0 \%$ between $R$. chensinensis, 3.3-3.5\% between $R$. huanrensis, and $6.2-6.4 \%$ between syntopic $R$. tsushimensis Stejneger, 1907 (Matsui, unpublished data); the degree of divergence is greater than that usually representing differentiation at the species level in frogs.

\section{Range}

Tsushima Island of Japan. Korean Peninsula and several adjacent small islands including Cheju Island (Kim et al., 2002; National Institute of Biological Resources, 2011).

\section{Natural history}

Rana uenoi inhabits mainly in wooded regions. Breeding is made in paddy fields, swamps, ponds, and river pools from mid February to March. Eggs are laid in relatively large and loose masses, floating on the surface of water. Hibernation is done in the water, mainly at the bottom of stony streams. On Tsushima Island, the new species coinhabits $R$. tsushimensis, but is less abundant and the breeding season is shorter in period although overlapping. In some areas of South Korea, R. uenoi is sympatric with $R$. huanrensis, which occurs only at valley in relatively high montane regions, and spawns on the rocks in streams (Kim et al., 2002).

\section{Conservation status}

Rana uenoi (as R. dybowskii) is listed as Near Threatened in Japanese Red List, but as Least Concerned in Korean Red Data Book (National Institute of Biological Resources, 2011) and IUCN categories (IUCN, 2013).

\section{DISCUSSION}

Heterospecific relationship of $R$. uenoi from Tsushima and $R$. dybowskii from the continent was suggested by Matsui (1991) from the results of isozyme analyses, where a greater genetic distance was found between Tsushima and Russian populations of $R$. dybowskii than between the latter and $R$. pirica. Similarly, Nishioka et al. (1992) found the genetic distance of $R$. dybowskii from Tsushima and $R$. chensinensis from Siberia (now regarded as $R$. dybowskii: Kuzmin and Maslova, 2003) to be as great as the distance between two distinct brown frog species, $R$. japonica Boulenger, 1879 and $R$. kobai Matsui, 2011 (as R. okinavana Boettger, 1895). Later analysis of mtDNA sequence also found a considerable genetic differentiation between populations of $R$. dybowskii from Tsushima and Russia (TanakaUeno et al., 1998).

The Korean brown frog, now called $R$. dybowskii, is clearly conspecific with $R$. uenoi. Long after the preliminary study of Ueda (1969), Kawamura et al. (1981) performed artificial hybridization reciprocally between the brown frogs from Tsushima and Korea and obtained normal, fertile hybrids, although Nishioka et al. (1987) found a very small karyotypic difference between the two populations. Furthermore, Matsui et al. (1998) found very small nucleotide sequence divergences between the two populations, with the range overlap of variations between the Korean and the Tsushima populations.

Green and Borkin (1993) reported that $R$. dybowskii from Russia (as $R$. chensinensis semiplicata) is more distant from $R$. dybowskii from Korea than from $R$. pirica (as $R$. c. chensinensis) from Kunashiri. Later mtDNA analyses revealed that populations of $R$. dybowskii from Tsushima and Korea are divergent from the Russian population in sequence divergences in a same degree as is found between clearly different species of brown frogs such as $R$. pirica and $R$. ornativentris (Tanaka et al., 1996). In this way, there is little doubt that $R$. uenoi from Tsushima and Korea is distantly related to the Russian $R$. dybowskii as to other brown frogs.

Little sequence divergence observed between populations of $R$. uenoi from Tsushima and Korea (Matsui et al., 1998 ) indicates a history gene flow between them until very recently. The fact that $R$. uenoi widely occurs in the Korean Peninsula, but is not found in regions east of Tsushima indicates its continental origin and the direction of migration from the Korean Peninsula to Tsushima Island. Invasion of the island seems to have occurred fairly recently, due to its low degree of genetic divergence from the Korean population. Further, the fact that the new species is less frequently encountered and its breeding sites are much narrower than $R$. tsushimensis on Tsushima Island seems to support this idea. Opposite interpretation of rarity and narrowness of $R$. uenoi on Tsushima, i.e., its old invasion and current relict status on the island, as is assumed for Odorrana utsunomiyaorum Matsui, 1994 in the southern Ryukyus (Matsui, 1994), cannot be applied to $R$. uenoi from its close sequence similarity between Tsushima and Korea.

The body size of two species of Rana on Tsushima Island has diverged toward both large $(=R$. uenoi, mean SVL of $62 \mathrm{~mm}$ in males and $76 \mathrm{~mm}$ in females) and small (=R. tsushimensis, $35 \mathrm{~mm}$ and $43 \mathrm{~mm}$, respectively [Maeda and Matsui, 1999]). In the Korean Peninsula, R. uenoi cooccurs with smaller $R$. coreana (mean SVL of $38 \mathrm{~mm}$ in males and $44 \mathrm{~mm}$ in females [Song et al., 2006]). As introduced by Matsui (1994), the body size differs among species whose feeding site and feeding time are same, and marked differentiation in the body size in the two species are regarded basically as a response to a strong interspecific competition pressure. Since R. uenoi from Tsushima Island 
largely overlaps in SVL with the Korean population, separation in SVL from $R$. tsushimensis cannot be regarded as a result of a character displacement in the small island.

Matsui (1994) sought to explain the body size difference of two species of the Odorrana (as Rana) narina complex in the southern Ryukyus by a coevolution-invasion hypothesis. The same model may be applied in part to the two brown frog species on Tsushima according to the following scenario. Geologically, the island has once been completely separated at $1.7 \mathrm{Ma}$, in the early Pleistocene, by the formation of the Korean Strait (= Busan and Tsushima Straits: Kim et al., 2007). Probably before this separation, prototsushimensis invaded the area, where it evolved to a characteristic size corresponding to the highest carrying capacity after the island was isolated. Next, when the Tsushima was connected again by the land bridge around $0.15-0.07 \mathrm{Ma}$ during the Riss-Wurm interglacial, the island was invaded by larger proto-uenoi that could invade because of asymmetry in the competition, and the both species coevolved as competitors. It is possible that further eastward invasions of $R$. uenoi populations were interrupted by the presence of $R$. ornativentris lineage, with only a slightly smaller body size (mean SVL of $48 \mathrm{~mm}$ in males and $68 \mathrm{~mm}$ in females [Maeda and Matsui, 1999]), in the present mainland Japan. Finally, the Tsushima Island was completely separated by the closure of the Busan and the Tsushima Straits after the latest glaciation (0.01-0.07 MYBP). Because of this very short period of co-existence on the island, promotion of the body size of tsushimensis to become smaller, and the invaded uenoi's body size to shift towards reducing competition, would be still in progress, if indeed it exists.

In the continent, $R$. dybowskii widely occurs from the Russian Far East to northeastern China (Xie et al., 1999; Kuzmin and Maslova, 2003; Che et al., 2007), but details of its distribution around northern Korea are unknown, although it surely occurs at least in Ryanggang-do (Song et al., 2006). Okada $(1928,1930)$ reported $R$. $t$. temporaria from northern Korea and Hokkaido, and $R$. $t$. ornativentris from southern Korea. Rana t. temporaria from Hokkaido is now known as $R$. pirica, while $R$. $t$. ornativentris was later changed to R. t. dybowskii (Shannon, 1956), which is here described as $R$. uenoi. It is highly improbable that $R$. pirica occurs in northern Korea, and the Okada's $(1928,1930) R$. $t$. temporaria from that region may be true $R$. dybowskii. What is more complicated is that another species $R$. huanrensis, with $2 \mathrm{n}=24$ chromosomes like $R$. uenoi and $R$. dybowskii (Xia et al., 2006), is now known to occur in both northern China and southern Korea (Yang et al., 2000). Thus, Okada's $(1928,1930)$ R. $t$. temporaria from northern Korea could be $R$. huanrensis. Future studies of the brown frogs from northern Korea are needed to clarify distributional relationships and divergence history of Korean $R$. uenoi and Russian R. dybowskii.

\section{ACKNOWLEDGMENTS}

I thank B. T. Clarke, S. Hatooka, S. Kawada, C. McCarthy, H. Nagaoka, Y. Shibata, and S.-I. Uéno for allowing me to examine specimens under their care, S.-L. Chen, K. Eto, T. Hikida, K. Kasugai, K. Matsuo, Y. Misawa, T. Nakano, H.-S. Oh, the late N.-K. Paik, the late S. Sengoku, S. Takenaka, S. Tanabe, S. Watanabe, and J. A. Wilkinson for help in collecting sample material, and J.-B. Kim for valuable information. The research was supported in part by grantsin-aid from the Ministry of Education, Science, Sports and Culture of Japan (Nos. 07454234, 10041166) and by a grant from The U. S. National Geographic Society (No. 4505-91).

\section{REFERENCES}

Che J, Pang JF, Zhao E-M, Matsui M, Zhang Y-P (2007) Phylogenetic relationships of the Chinese brown frogs (genus Rana) inferred from partial mitochondrial $12 S$ and 16S rRNA gene sequences. Zool Sci 24: 71-80

Fei L, Ye CY, Jiang JP, Xie F, Huang YZ (2005) An Illustrated Key to Chinese Amphibians. Sichuan Publishing House of Science and Technology, Chengdu

Gosner KL (1960) A simplified table for staging anuran embryos and larvae with note on identification. Herpetologica 16: 183-190

Green DM (1983) Evidence for chromosome number reduction and chromosomal homosequenciality in the 24 chromosome Korean frog Rana dybowskii and related species. Chromosoma 88: 222-226

Green DM, Borkin LJ (1993) Evolutionary relationships of eastern Palearctic brown frogs, genus Rana: Paraphyly of the 24chromosome species group and the significance of chromosome number change. Zool J Linn Soc 109: 1-25

Günther ACLG (1876) Description of a new frog from north-eastern Asia. Ann Mag Nat Hist Ser 4 17: 387

IUCN (2013) The IUCN Red List of Threatened Species Version 2013.2. IUCN, Gland, Switzerland. http://www.iucnredlist.org/

Kawamura T, Nishioka M, Ueda H (1981) Interspecific hybrids among Japanese, Formosan, European and American brown frogs. Sci Rep Lab Amph Biol Hiroshima Univ 5: 195-323

Kim J-B, Min M-S, Yang S-Y, Matsui M (2002) Genetic relationships among Korean brown frog species (Anura, Ranidae), with special reference to evolutionary divergences between two allied species Rana dybowskii and R. huanrenensis. Zool Sci 19: 369-382

Kuzmin SL, Maslova IV (2003) Amphibians of the Russian Far East. Adv Amphib Res Former Soviet Union 8: 1-462

Maeda N, Matsui M (1999) Frogs and toads of Japan, Revised Version. Bun-ichi Sogo Shuppan, Tokyo

Matsui M (1984) Morphometric variation analyses and revision of the Japanese toads (Genus Bufo, Bufonidae). Contrib Biol Lab Kyoto Univ 26: 209-428

Matsui M (1991) Original description of the brown frog from Hokkaido, Japan. Jpn J Herpetol 14: 63-78

Matsui M (1994) A taxonomic study of the Rana narina complex, with description of three new species (Amphibia: Ranidae). Zool J Linn Soc 111: 385-415

Matsui M, Wu G-F, Song M-T (1993) Morphometric comparisons of Rana chensinensis from Shaanxi with three Japanese brown frogs (Genus Rana). Jpn J Herpetol 15: 29-36

Matsui M, Tanaka-Ueno T, Paik N-K, Yang S-Y, Takenaka O (1998) Phylogenetic relationships among local populations of Rana dybowskii assessed by mitochondrial cytochrome b gene sequences. Jpn J Herpetol 17: 145-151

Matsui M, Hamidy A, Eto K (2013) Description of a new species of Microhyla from Bali, Indonesia (Amphibia, Anura). Zootaxa 3670: $579-590$

Nakamura K, Uéno S-I (1963) Japanese Reptiles and Amphibians in Colour. Hoikusha, Osaka

Nakamura K, Uéno S-I (1965) Japanese Reptiles and Amphibians in Colour. 2nd ed. Hoikusha, Osaka

National Institute of Biological Resources (2011) Endangered Amphibians and Reptiles in Korea. Nat Inst Biol Res, Seoul

Nishioka M, Okumoto H, Ueda H, Ryuzaki M (1987) Karyotypes of brown frogs distributed in Japan, Korea, Europe and North America. Sci Rep Lab Amph Biol Hiroshima Univ 9: 165-212 
Nishioka M, Sumida M, Borkin LJ, Wu Z (1992) Genetic differentiation of 30 populations of 12 brown frog species distributed in the Palearctic region elucidated by the electrophoretic method. Sci Rep Lab Amph Biol Hiroshima Univ 11: 109-160

Okada Y (1928) Frogs in Korea. J Chosen Nat Hist Soc 6: 15-46

Okada $Y$ (1930) Monograph of Japanese Tailless Batrachians. Iwanami-shoten, Tokyo

Savage JM (1975) Systematics and distribution of the Mexican and Central American stream frogs related to Eleutherodactylus rugulosus. Copeia 1975: 254-306

Sengoku S (ed) (1979) Amphibians and Reptiles in Color. Ie-noHikari Kyokai, Tokyo

Seto T (1965) Cytogenetic studies in lower vertebrates. II. Karyological studies of several species of frogs (Ranidae). Cytologia 30 : 437-446

Shannon FA (1956) The reptiles and amphibians of Korea. Herpetologica 12: 22-49

Song J-Y, Matsui M, Chung K-H, Oh H-S, Zhao W-G (2006) Distinct specific status of the Korean brown frog, Rana amurensis coreana (Amphibia; Ranidae). Zool Sci 23: 219-224

Tanaka T, Matsui M, Takenaka O (1996) Phylogenetic relationships of Japanese brown frogs (Rana: Ranidae) assessed by mitochondrial cytochrome b gene sequences. Biochem Syst Ecol 24: 299-307

Tanaka-Ueno T, Matsui M, Sato T, Takenaka S, Takenaka O (1998)
Phylogenetic relationships of brown frogs with 24 chromosomes from Far East Russia and Hokkaido assessed by mitochondrial cytochrome b gene sequences (Rana: Ranidae). Zool Sci 15: 289-294

Tanaka-Ueno T, Matsui M, Wu G-F, Fei L, Takenaka O (1999) Identity of Rana chensinensis from other brown frogs as assessed by mitochondrial cytochrome b sequences. Copeia 1999: 187190

Ueda H (1969) On reproductive isolation between four Japanese brown frog species and Korean R. temporaria dybowskii. Zool Mag Tokyo 78: 405

Uéno S-I, ShibataY (1970) A brief account of the herpetology of the islands of Tsushima. Mem Nat Sci Mus Tokyo 3: 193-198

Xia Y-G, Zhao W-G, Liu P, Liu L-L, Li J-Y, Liu Y-Q (2006) The karyotype of Rana huanrenesis and $R$. dybowskii from Huanren, Liaoning Province. Dongwuxue Zazhi (Chin J Zool) 41: 103106

Xie F, Ye C-Y, Fei L, Jiang J-P, Zeng X-M, Matsui M (1999) Taxonomical studies on brown frogs (Rana) from northeastern China (Amphibia: Ranidae). Acta Zootax Sinica 24: 224-231

Yang SY, Kim JB, Min M-S, Suh J-H, Kang Y-J, Matsui M, et al. (2000) First record of a brown frog Rana huanrenensis (Family Ranidae) from Korea. Kor J Biol Sci 4: 45-50

(Received April 10, 2014 / Accepted May 9, 2014) 